\title{
Bcl-2 proteins regulate ER membrane permeability to luminal proteins during ER stress-induced apoptosis
}

\author{
X Wang ${ }^{1}$, KE Olberding ${ }^{1}$, C White ${ }^{2}$ and $C$ Li $^{*, 1}$
}

Endoplasmic reticulum (ER) stress-induced apoptosis may arise from multiple environmental and pharmacological causes, but the precise mechanism(s) involved are not completely known. Members of Bcl-2 protein family are important regulators of apoptosis. In this study, we report that in a process dependent on the proapoptotic Bcl-2 members Bax and Bak, exogenously expressed fluorescent protein localized to the ER lumen is released into the cytosol in cells undergoing ER stress. Upon ER stress induction, endogenous ER luminal proteins are also released into the cytosol in a similar manner accompanied by translocation and anchorage of Bax to the ER membrane. In addition, Bax and truncated-Bid (tBid) mediate a global increase in ER membrane permeability to ER luminal proteins in vitro. Importantly, antiapoptotic Bcl- $X_{L}$ antagonizes the effects of proapoptotic Bcl-2 proteins on ER membrane permeability. Consistent with Bax translocation to the ER membrane in whole apoptotic cells, there is also increased tight association of Bax with the ER membrane correlated with the increase in ER membrane permeability in vitro. Overall, these data suggest that the regulation of ER membrane permeability by Bcl-2 proteins could be an important molecular mechanism of ER stress-induced apoptosis.

Cell Death and Differentiation (2011) 18, 38-47; doi:10.1038/cdd.2010.68; published online 11 June 2010

Bcl-2 proteins are among the major regulators of apoptotic signaling. ${ }^{1-4}$ The Bcl-2 protein family includes both antiapoptotic and proapoptotic members that share one or more homologous domains, named the $\mathrm{Bcl}-2$ homology $(\mathrm{BH})$ domains. There are two groups of proapoptotic $\mathrm{Bcl}-2$ proteins: multiple $\mathrm{BH}$ domain proteins and $\mathrm{BH}$ domain-only proteins. Multiple $\mathrm{BH}$ domain members Bak and Bax are redundant promoters of cell death and either Bak or Bax is sufficient to trigger apoptosis under apoptotic conditions. ${ }^{5,6} \mathrm{BH} 3-$ only $\mathrm{Bcl}-2$ proteins are usually kept inactive by different mechanisms. In response to various death stimuli, BH3-only proteins are activated and function as effectors of apoptotic signaling pathways. ${ }^{1,2} \mathrm{Bcl}-2$ proteins differentially interact with each other and with other regulators of apoptotic signaling, thus profoundly influencing the regulation of survival and death.

Bcl-2 proteins have been shown to localize to the mitochondria, the endoplasmic reticulum (ER), and the nuclear envelope. ${ }^{7}$ Most studies have focused on how $\mathrm{Bcl}-2$ proteins function on mitochondria. A common theme is that permeabilization of the mitochondrial outer membrane (MOM) causes the release of apoptogenic factors from mitochondria into the cytosol. ${ }^{2,4,8}$ These apoptogenic factors subsequently activate a class of aspartate-directed cysteine proteases (caspases), which exist in healthy cells as inactive proenzymes and are activated through a cascade of caspase cleavages. ${ }^{9}$ It is generally believed that antiapoptotic $\mathrm{Bcl}-2$ family members help to maintain MOM integrity during apoptosis, whereas proapoptotic Bcl-2 proteins facilitate its disintegration. ${ }^{2,4}$

A large body of evidence indicates that Bcl-2 proteins can sense damage to the ER and either transmit death signals to mitochondria or directly function at the ER level to regulate apoptosis. ${ }^{10,11}$ Recent studies have shown that ER membrane permeability to $\mathrm{Ca}^{2+}$ is altered by activation of the proapoptotic Bcl-2 proteins in cells undergoing apoptosis. ${ }^{12-15}$ However, it is not known whether ER membrane permeability to luminal proteins is altered in apoptotic cells. In this study, we explored the role of Bcl-2 proteins in the regulation of ER membrane permeability to luminal proteins. We observed that ER luminal proteins were released into the cytosol during ER stress-induced apoptosis in a Bak/Bax-dependent manner. Furthermore, Bcl-2 proteins were also able to regulate ER membrane permeability in vitro in a manner similar to their activities on the MOM. Our findings provide evidence that $\mathrm{Bcl}-2$ proteins regulate $\mathrm{ER}$ membrane permeability to luminal proteins during apoptosis.

\section{Results}

ER stress induces Bak/Bax-dependent increases in ER membrane permeability. To monitor ER membrane permeability in cells undergoing apoptosis, time-lapse confocal microscopy was used to image the localization of an ER luminal marker in single living cells. Wild-type mouse

\footnotetext{
${ }^{1}$ Molecular Targets Group, James Graham Brown Cancer Center, Departments of Medicine, and Pharmacology and Toxicology, University of Louisville, Louisville, KY 40202, USA and ${ }^{2}$ Department of Physiology and Biophysics, Rosalind Franklin University of Medicine and Science, North Chicago, IL 60064, USA

${ }^{*}$ Corresponding author: C Li, Clinical Translational Research, Room 418, 505 South Hancock Street, Louisville, KY 40202, USA. Tel: +502 852 0600;

Fax: + 502852 3661; E-mail: chi.li@louisville.edu

Keywords: endoplasmic reticulum; Bcl-2 protein; membrane permeability; apoptosis

Abbreviations: ER, endoplasmic reticulum; MOM, mitochondrial outer membrane; MEF, mouse embryonic fibroblast; PDI, protein disulfide isomerase; GRP78/BiP, 78-kDa glucose-regulated protein; tBid, truncated-Bid; TMRE, tetramethylrhodamine, ethyl ester

Received 08.9.09; revised 13.4.10; accepted 03.5.10; Edited by C Borner; published online 11.6.10
} 
embryonic fibroblast (MEF) cells were transiently transfected with a plasmid encoding yellow fluorescence protein targeted to the ER lumen (ER-YFP). Cells were treated with ER stress inducers thapsigargin (an inhibitor of sarco/ ER $\mathrm{Ca}^{2+}$ ATPase) or tunicamycin (an inhibitor of $\mathrm{N}$-linked glycosylation) and an image field was acquired over the course of $10 \mathrm{~h}$ (Figure 1a; Supplementary Movies 1 and 2). Before thapsigargin or tunicamycin application, the cellular fluorescence distribution was punctate and reticular, consistent with ER luminal localization. ${ }^{16}$ Addition of thapsigargin or tunicamycin induced a redistribution of YFP in about 40 and $50 \%$ of cells, respectively (Figure 1c), from an ER localization to an evenly dispersed cytoplasmic and nuclear distribution (Figure 1a). In addition, both reagents were able to release YFP with identical kinetics (Figure 1d). The release of ER-YFP is unlikely to be the result of simple ER membrane destruction, as wild-type MEFs treated with thapsigargin or tunicamycin for $10 \mathrm{~h}$ had similar ER membrane topology to untreated cells when examined using electron microscopy (Supplementary Figure 1). When experiments were repeated using $\mathrm{Bak}^{-1-} \mathrm{Bax}^{-1-}$ MEF cells, in contrast to wild-type cells, redistribution of ER-YFP occurred in less than $5 \%$ of treated cells (Figure 1b and c; Supplementary Movies 3 and 4). Taken together, these observations are consistent with the hypothesis that Bak/Bax-dependent changes in ER permeability during ER stress can facilitate the release of high molecular weight ER luminal proteins.

These findings raise the possibility that such a mechanism may not be limited to ER stress, but represent a common feature of multiple apoptotic paradigms. To explore this prospect further, the effect of the genotoxic reagent actinomycin $D$ on ER membrane permeability was tested on wild-type MEF cells expressing ER-YFP (Figure 1e; Supplementary Movie 5). Actinomycin $D$ induced shrinkage and detachment of all cells within the $10 \mathrm{~h}$ recording period. No redistribution of ER-localized YFP was observed during this time, with the YFP being retained within highly localized puncta until cell detachment. These data suggest that early, Bak/Bax-dependent alterations in ER membrane permeability may be an exclusive feature of ER stress-induced apoptosis.

The role of Bak/Bax in MOM permeabilization and the release of cytochrome $c$ are well established for many apoptotic paradigms. ${ }^{2,4}$ The requirement for Bak/Bax to increase ER permeability during ER stress could either be a

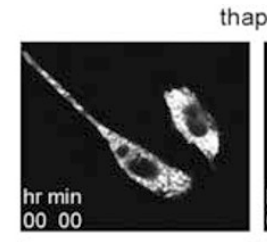

thapsigargin-treated WT cells
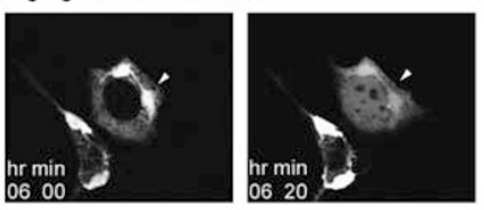

tunicamycin-treated WT cells
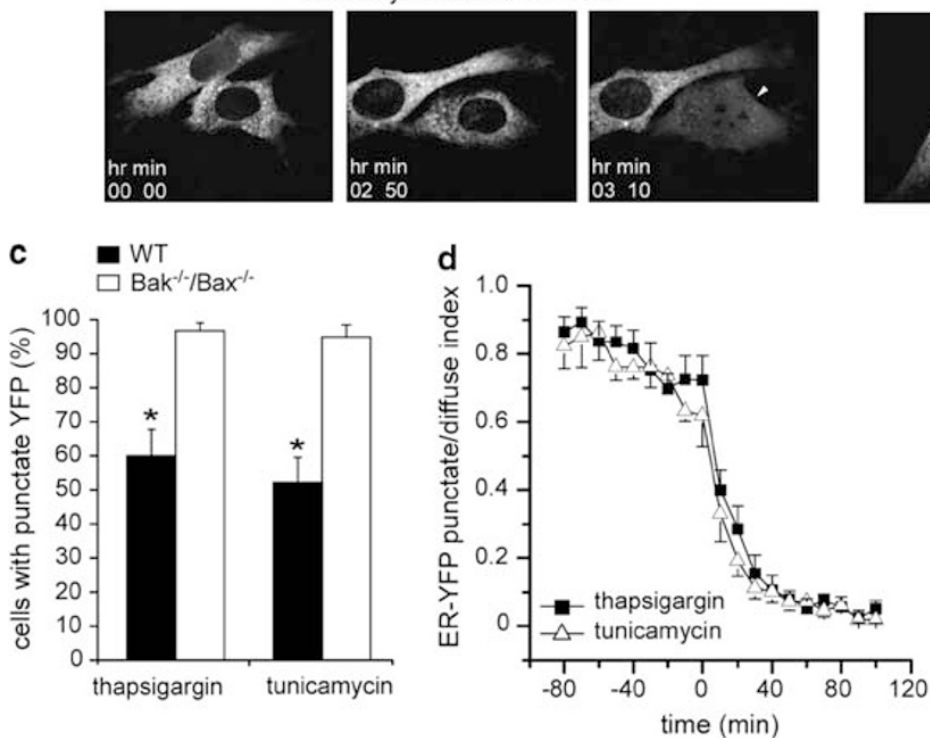
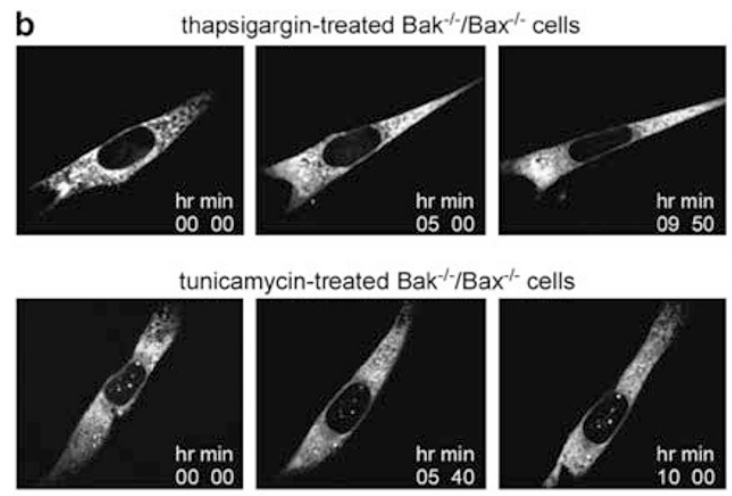

e

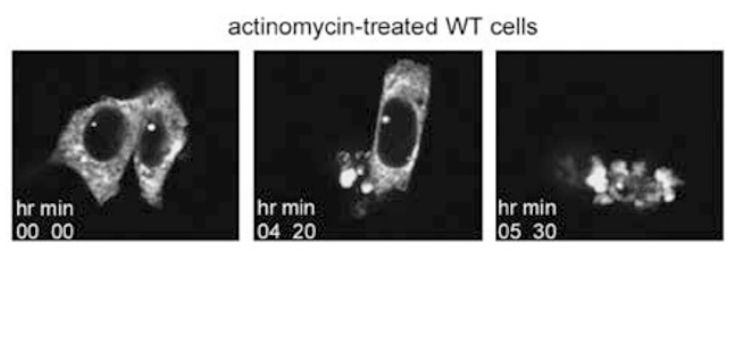

Figure 1 ER stress induces Bak/Bax-dependent redistribution of ER-targeted YFP. Wild-type MEF cells were transiently transfected with a construct encoding yellow fluorescence protein targeted to the ER lumen (pYFP-ER). (a) The subcellular localization of YFP monitored by time-lapse confocal microscopy in cells treated with $1 \mu \mathrm{M}$ thapsigargin or $0.5 \mu \mathrm{g} / \mathrm{ml}$ tunicamycin. Confocal images at the indicated time points after the addition of the indicated reagents are shown. Arrow heads mark the cells in which YFP release from the ER compartment is visualized as a change in fluorescence distribution from punctate to diffuse. (b) Visualization of ER-YFP fluorescence in thapsigargin$(1 \mu \mathrm{M})$ or tunicamycin $(0.5 \mu \mathrm{g} / \mathrm{ml})$-treated Bak ${ }^{-1-} / \mathrm{Bax}^{-1-} \mathrm{MEF}$ cells. (c) Summary bar graphs showing the percentage of cells (mean \pm S.E.M.; $N \geq 40$ cells pooled from four independent trials) with ER-localized YFP after $10 \mathrm{~h}$ in the presence of thapsigargin or tunicamycin $\left({ }^{*} P<0.001\right.$; Fisher's exact test). (d) The kinetics of ER-YFP release in wildtype MEF cells treated with thapsigargin or tunicamycin. Summary data showing the mean \pm S.E.M. of the scaled punctuate/diffuse index calculated for at least 40 cells in four independent experiments and aligned so that ER-YFP release occurs when $t=0$. (e) Representative confocal images of wild-type MEF cells treated with $0.25 \mu \mathrm{g} / \mathrm{ml}$ actinomycin $\mathrm{D}$. The representative experiments shown in $\mathbf{a}, \mathbf{b}$ and $\mathbf{e}$ are also presented as time-lapse movies in the Supplementary Material 
a thapsigargin-treated WT cells

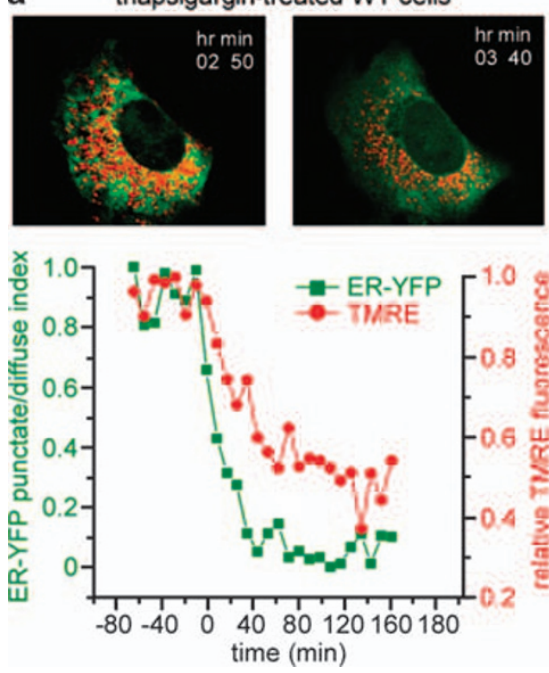

b

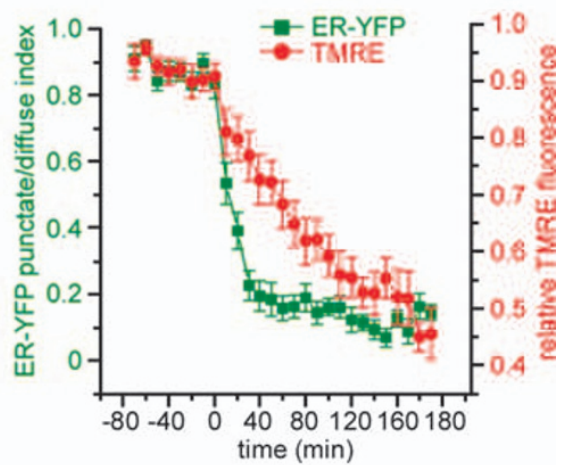

Figure 2 Redistribution of ER-targeted YFP occurs in parallel with mitochondrial membrane potential changes during ER stress. Wild-type MEF cells transiently expressing ER-targeted YFP and co-labeled with TMRE were treated with thapsigargin $(1 \mu \mathrm{M})$ and imaged at $10 \mathrm{~min}$ intervals. (a) Confocal slices of a representative cells showing the distribution of ER-YFP (green) and TMRE (red) fluorescence immediately before and after YFP redistributes from punctate to diffuse localization. The scaled punctate/diffuse index is plotted along with the relative TMRE fluorescence for the depicted cell and aligned so that ER-YFP release occurs when $t=0$. (b) Summary data showing the kinetics of ER-YFP release and mitochondrial membrane potential changes. Depicted is the scaled ER-YFP punctuate/diffuse index along with TMRE fluorescence plotted against time for the mean \pm S.E.M. of 15 cells pooled from three independent experiments

because of the direct actions of Bak/Bax at the membrane or reflect signaling events secondary to Bak/Bax-dependent effects at mitochondria. If the former possibility was correct, then ER and mitochondrial membrane disruption should occur simultaneously, whereas MOM permeabilization would be expected to occur upstream of any ER-localized event in the latter case. To discriminate between these possibilities, the time course of mitochondrial membrane potential changes and ER-YFP release were monitored simultaneously during thapsigargin exposure. Mitochondrial membrane potential dissipates during apoptosis as a direct result of increased MOM permeability and has been widely used as an index of cytochrome $c$ release. ${ }^{17-19}$ Wild-type MEF cells expressing ER-YFP were loaded with the mitochondrial membrane potential probe, tetramethylrhodamine, ethyl ester (TMRE), and with cells treated with thapsigargin (Figure 2a). The timelapse data show that mitochondrial membrane potential dissipation is initiated in parallel with the redistribution of ER-localized YFP (Figure 2b), showing that disruption of both mitochondrial and ER membrane integrity occurs concomitantly. This is consistent with the hypothesis that Bak/Bax activation alone is sufficient to trigger ER membrane disruption, which is unlikely to be downstream of MOM permeabilization.

Endogenous ER luminal proteins are released into the cytosol during ER stress-induced apoptosis. To determine whether ER membrane permeability to endogenous ER luminal proteins is also altered on ER stress, both wild-type and $\mathrm{Bak}^{-1-} \mathrm{Bax}^{-1-} \mathrm{MEF}$ cells were treated with thapsigargin, and the presence of the ER luminal proteins protein disulfide isomerase (PDI) and $78-\mathrm{kDa}$ glucoseregulated protein (GRP78/BiP) in cytosolic fractions was determined by western blotting (Figure 3a). The levels of PDI and GRP78/BiP in cytosolic fractions of $\mathrm{Bak}^{-1-} \mathrm{Bax}^{-1-}$ cells were unchanged upon thapsigargin treatment. However, the amounts of PDI and GRP78/BiP were notably higher in cytosolic fractions of thapsigargin-treated wild-type cells than those of untreated cells, consistent with previously observed redistribution of ER-localized YFP in cells under ER stress (Figure 1). The absence of ER membrane protein calnexin indicated that cytosolic fractions were free of $\mathrm{ER} / \mathrm{microsomal}$ contamination. Similar results were obtained with interleukin 3 (IL-3)-dependent hematopoietic cells, suggesting that increased ER membrane permeability in response to ER stress is independent of cell lineage (Supplementary Figure 2). Importantly, when wild-type MEF cells were treated with thapsigargin, tunicamycin, actinomycin $D$, or staurosporine at the time points in which the levels of cell death were similar (Figure 3b), PDI and GRP78/Bip release was observed in cells treated with thapsigargin or tunicamycin, but not in those treated with actinomycin D or staurosporine (Figure 3c), providing further evidence that alterations in ER membrane permeability occur only in ER stress-induced apoptosis. To determine whether ER luminal proteins are released into the cytosol as monomeric proteins or in macromolecular complexes, we loaded cytosolic fractions of thapsigargin-treated wild-type MEF cells onto a FPLC Superose 6 gel filtration column (GE Healthcare, Piscataway, NJ, USA). PDI and GRP78/Bip were exclusively detected in late elution fractions containing molecules whose molecular weights are within the same range of those of PDI and GRP78/Bip, indicating that released ER luminal proteins were not in macromolecular complexes, such as lipid vesicles (Figure 3d). Overall, these data suggest that ER membrane permeability to endogenous luminal proteins is altered during ER stress-induced cell death, which depends on the presence of Bax and Bak. 

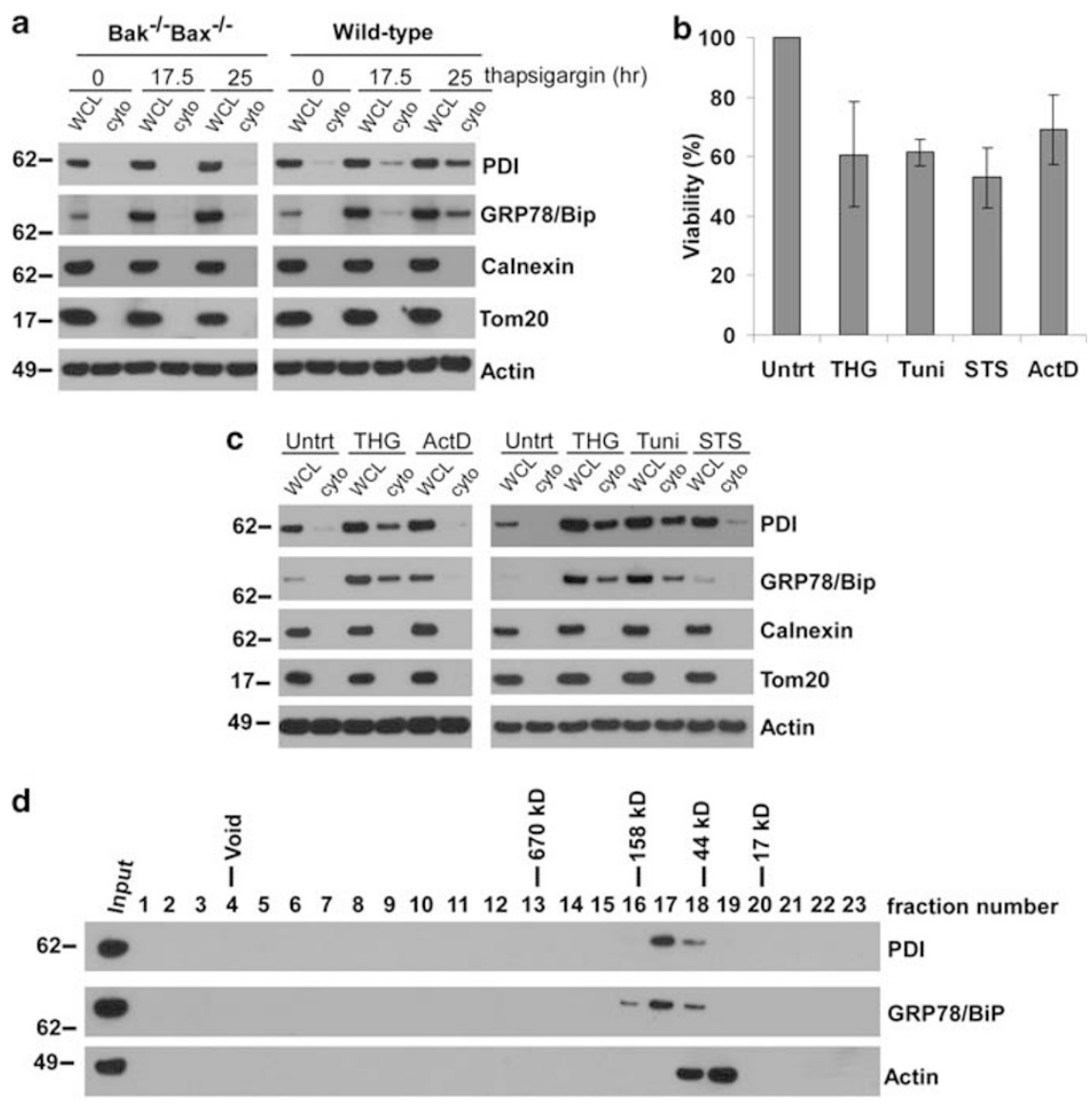

Figure 3 The endogenous ER luminal proteins are released into the cytosol on thapsigargin treatment. (a) Wild-type and Bak ${ }^{-1-} \mathrm{Bax}^{-1-} \mathrm{MEF}$ cells were treated with $5 \mu \mathrm{M}$ thapsigargin. ER chaperones PDI and GRP78/Bip in cytosolic fractions at the indicated time points were detected by western blotting. WCL, whole cell lysate; cyto, cytosolic. (b) The levels of wild-type MEF cell death induced by THG (thapsigargin, $5 \mu \mathrm{M}$ for $25 \mathrm{~h}$ ), Tuni (tunicamycin, $0.5 \mu \mathrm{g} / \mathrm{ml}$ for $22 \mathrm{~h}$ ), STS (Staurosporine, $5 \mathrm{nM}$ for $24 \mathrm{~h}$ ), or ActD, (actinomycin D, $0.25 \mu \mathrm{g} / \mathrm{ml}$ for $20 \mathrm{~h}$ ) were comparable. Cell death was measured by propidium iodide exclusion. Mean \pm S.D. of three independent experiments are shown. Untrt, untreated. (c) Wild-type MEF cells were treated with the apoptotic stimuli as shown in $\mathbf{b}$. The amounts of ER luminal proteins in cytosolic fractions were determined by western blotting. Untrt, untreated. (d) Gel filtration analysis of ER luminal proteins released into the cytosol. The cytosolic fractions of wild-type MEF cells treated with $5 \mu \mathrm{M}$ thapsigargin for $17.5 \mathrm{~h}$ were analyzed on a Superose 6 column. The presence of PDI and GRP78/Bip in each gel filtration fraction was examined by western blotting. The molecular weights of protein standards were indicated

ER stress induces Bax translocation and insertion into the ER membrane. As Bax translocation to mitochondria has been shown to be critical to MOM permeabilization, ${ }^{4,20}$ we explored the role of Bax translocation to the ER membrane in ER membrane permeabilization. We carried out subcellular fractionation of both wild-type MEF cells (Figure 4a) and IL-3-dependent cells reexpressing Bak and Bax (Figure 4b) under ER stress. ER/microsomal fractions were not contaminated with mitochondria, as indicated by the absence of Tom20. In agreement with previous reports, ${ }^{13,21}$ a modest amount of Bax was detected on the ER membrane in untreated cells. However, the levels of Bax in ER/microsomal fractions of cells under ER stress were higher than those of untreated cells. This trend was also observed when $\mathrm{ER} /$ microsomal fractions were incubated with $100 \mathrm{mM}$ $\mathrm{Na}_{2} \mathrm{CO}_{3}$ ( $\mathrm{pH}$ 11.3) to remove peripheral ER membrane proteins, ${ }^{22}$ suggesting that translocated Bax was tightly anchored to the ER membrane. Furthermore, Bax oligomerization on the ER membrane in IL-3-dependent cells was also increased by thapsigargin, indicated by the increased intensity of slowly migrating bands recognized by Bax antibodies after treatment with the chemical cross-linking agent bismaleimidohexane (BMH) (Supplementary Figure 3). These results reveal a correlation between Bax translocation to the ER membrane and the increase in ER membrane permeability.

Bcl-2 proteins modulate ER membrane permeability in vitro. To investigate the direct effects of $\mathrm{Bcl}-2$ proteins on ER membrane permeability to luminal proteins, we developed a reconstituted in vitro assay to recapitulate the alterations in ER membrane permeabilization observed in intact cells under ER stress. Studies were focused on Bax and an active form of the BH3-only protein Bid, truncated-Bid (tBid), which has been shown to translocate to the ER and mediate ER stress-induced apoptosis. ${ }^{23,24}$ As the ER luminal protein $\mathrm{PDI}$ was released during ER stress-induced cell death (Figure 3a), we investigated the permeability of $\mathrm{ER} /$ microsomal vesicles to PDI as an index of ER membrane permeabilization in vitro. ER/microsomal vesicles were 

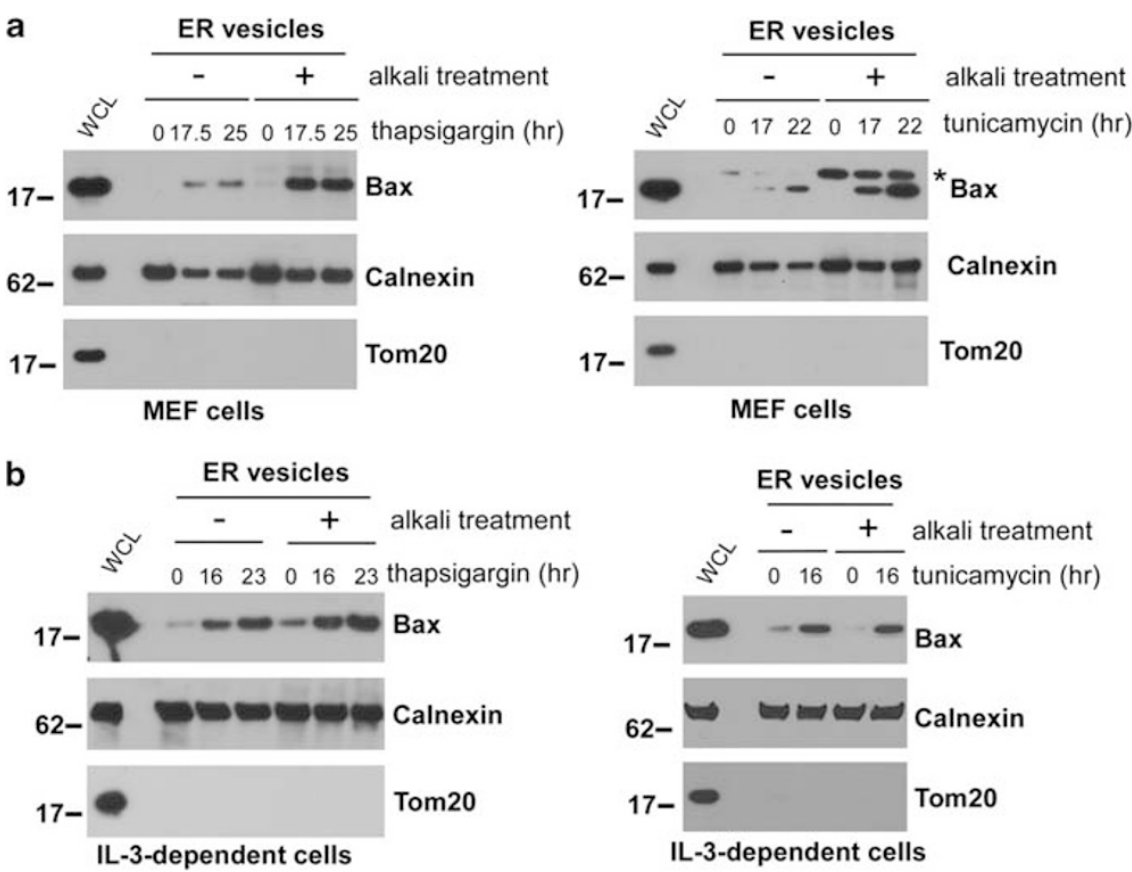

Figure $4 \mathrm{ER}$ stress induces the translocation of Bax protein to the ER membrane. (a) Wild-type MEFs were treated with $5 \mu \mathrm{M}$ thapsigargin or $0.5 \mu \mathrm{g} / \mathrm{ml}$ tunicamycin $\mathrm{ER} /$ microsomal vesicles of treated cells were obtained at the indicated time points and incubated with or without alkali treatment $\left(100 \mathrm{mM} \mathrm{Na} \mathrm{CO}_{3}(\mathrm{pH} 11.3)\right) . \mathrm{Bax}$ in $\mathrm{ER} /$ microsomal fractions was detected by western blotting. A cross-reacting band with higher molecular weight is indicated by an asterisk. (b) IL-3-dependent Bak ${ }^{-1-} \mathrm{Bax}^{-1-}$ cells reexpressing Bak and Bax were treated with $30 \mathrm{nM}$ thapsigargin or $3 \mu \mathrm{g} / \mathrm{ml}$ tunicamycin. Purified ER/microsomal vesicles were treated and incubated with or without alkali treatment. The amounts of Bax protein in ER/microsomal fractions were determined by western blotting
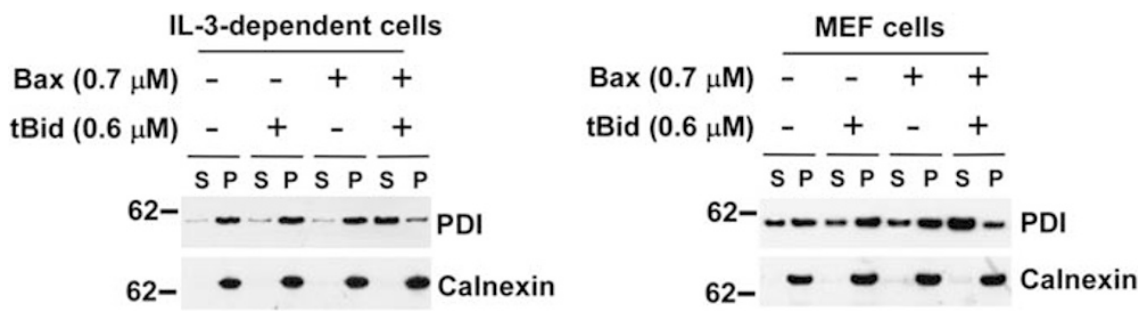

Figure 5 The Bcl-2 proteins Bax and tBid increase ER membrane permeability in vitro. ER/microsomal vesicles were purified from IL-3-dependent Bak ${ }^{-1-}$ Bax $^{-I-}$ cells $^{-}$ or Bak ${ }^{-1-} \mathrm{Bax}^{-1-}$ MEF cells and incubated with the indicated recombinant Bcl-2 proteins, as described in Materials and Methods. The presence of the ER luminal protein $\mathrm{PDI}$ in the $\mathrm{ER} /$ microsomal vesicle fractions $(\mathrm{P}$, pellet) or the released fractions $(\mathrm{S}$, supernatant) was detected by western blotting

purified from $\mathrm{Bak}^{-1-} \mathrm{Bax}^{-1-}$ IL-3-dependent cells or MEF cells and incubated with Bax alone, tBid alone or with both at $37^{\circ} \mathrm{C}$. After ultracentrifugation, the amount of PDI in both the supernatant (released fraction) and the pellet (ER vesicle membrane fraction) was detected by western blotting (Figure 5). Bax or tBid alone did not enhance PDI release. However, combining Bax and tBid led to a considerable increase in PDI in the supernatant fraction and a decrease in PDI in the vesicle membrane fraction, indicating an increase in ER vesicle membrane permeability. Furthermore, the ER membrane protein, calnexin, was retained in the membrane fraction, suggesting that the increased ER membrane permeability did not lead to the overall destruction of ER membrane structure.

To further characterize the increase in ER membrane permeability mediated by proapoptotic $\mathrm{Bcl}-2$ proteins in vitro, we examined whether ER luminal proteins other than PDI were also released. ER/microsomal vesicles isolated from $\mathrm{Bak}^{-1-} \mathrm{Bax}^{-1-}$ IL-3-dependent cells were incubated with Bax and different dosages of tBid (Figure 6). As the tBid concentration increased, more PDI was released from microsomal vesicles. Two other ER luminal proteins, ERp29 and GRP78/BiP, were also detected in the released fractions. Importantly, tBid was equally effective in releasing all three ER luminal proteins in the presence of Bax, suggesting that the permeation channels formed by Bax and tBid on the ER membrane are nonselective (Figure 6b). This observation is consistent with the reported Bax/tBid-mediated supramolecular permeation channels formed in the $\mathrm{MOM},{ }^{25}$ suggesting that proapoptotic $\mathrm{Bcl}-2$ proteins mediate ER membrane permeabilization in a manner similar to their activities on the MOM.

In addition to Bid, several other BH3-only $\mathrm{Bcl}-2$ proteins have also been implicated in ER stress-induced 


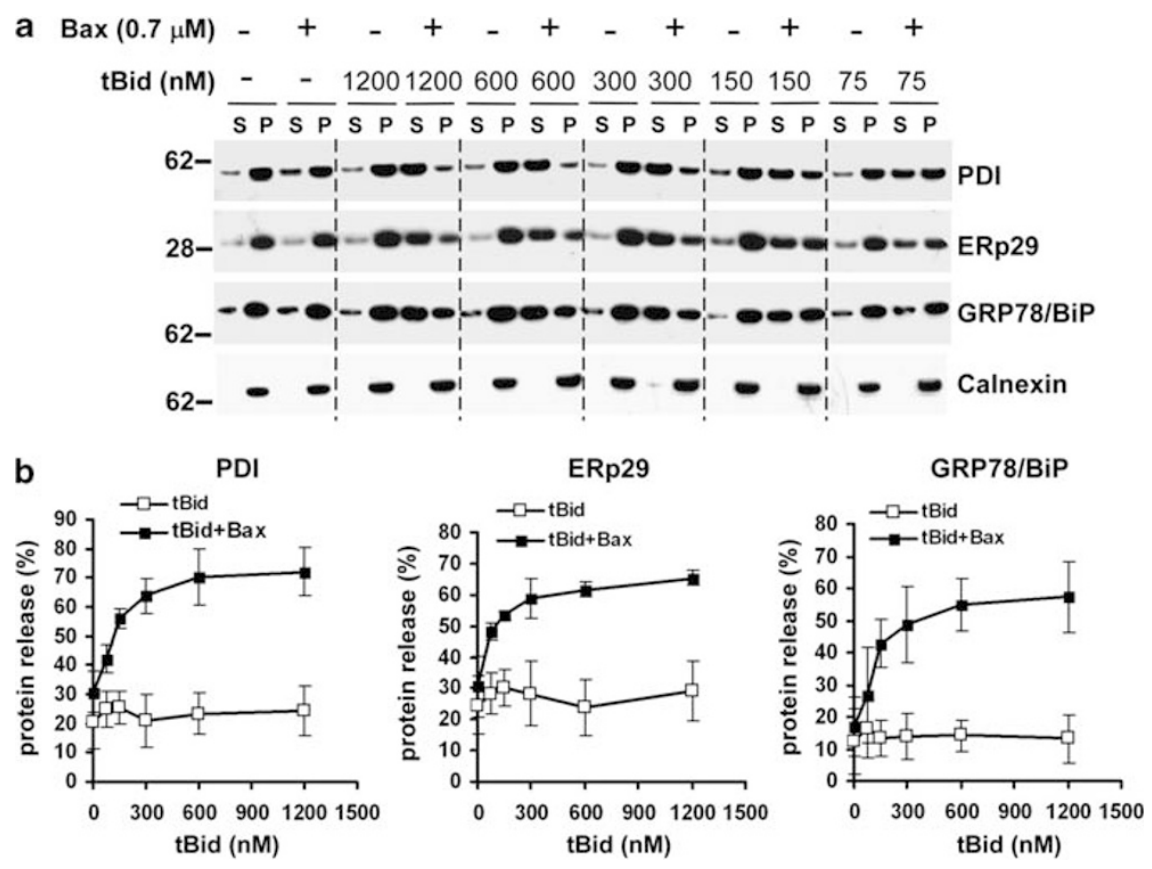

Figure 6 Different ER luminal proteins are released in a similar manner in vitro. (a) ER lumen proteins are released in a tBid dosage-dependent manner. ER/microsomal vesicles isolated from IL-3-dependent $\mathrm{Bak}^{-l-} \mathrm{Bax}^{-l-}$ cells were incubated with the indicated concentrations of Bax and tBid for 60 min. The presence of the ER luminal proteins PDI, ERp29, and GRP78/BiP in ER/microsomal fractions (P, pellet) and released fractions (S, supernatant) was determined by western blotting. (b) The intensities of $\mathrm{PDI}, \mathrm{ER} 29$, and GRP78/BiP in ER/microsomal vesicle fractions and released fractions shown in a were quantified using ImageJ software (NIH). ER luminal protein release is represented as a percentage of the sum of the protein intensity in supernatant and pellet. Mean \pm S.D. for three independent experiments are shown

Table $1 \mathrm{BH} 3$ peptides derived from various $\mathrm{BH} 3$-only proteins display different ability to permeabilize the ER membrane

\begin{tabular}{|c|c|c|}
\hline $\begin{array}{l}\text { BH3 } \\
\text { peptide }\end{array}$ & Sequence & $\begin{array}{c}\text { Ability to } \\
\text { permeabilize } \\
\text { the ER } \\
\text { membrane }\end{array}$ \\
\hline Bid & QEDIIRNIARHLAQVGDSMDRSIPP & + \\
\hline $\mathrm{Bim}$ & DNRPEIWIAQELRRIGDEFNAYYAR & + \\
\hline Bmf & LQHRAEVQIARKLQCIADQFHRLHT & + \\
\hline Puma & EEQWAREIGAQLRRMADDLNAQYER & $+1-$ \\
\hline Noxa B & VPADLKDECAQLRRIGDKVNLRQKL & $+1-$ \\
\hline Bad & NLWAAQRYGRELRRMSDEFVDSFKK & - \\
\hline BNIP3 & DIERRKEVESILKKNSDWIWDWSS & - \\
\hline & CMEGSDALALRLACIGDEMDVSLRA & - \\
\hline HRK & LRSSAAQLTAARLKALGDELHQRTM & - \\
\hline Bax & PQDASTKKSECLKRIGDELDSNMEL & - \\
\hline
\end{tabular}

The ability of the indicated $\mathrm{BH} 3$ peptides to compromise ER membrane permeability to ER luminal proteins in the presence of Bax was summarized.

apoptosis. $^{26-28}$ As $\mathrm{BH} 3$ regions of $\mathrm{BH} 3$-only proteins have been shown to differentially regulate Bax-mediated MOM permeabilization, ${ }^{29,30}$ we sought to study the ability of various BH3-only Bcl-2 proteins to modulate Bax-mediated ER membrane permeabilization. ER/microsomal vesicles isolated from $\mathrm{Bak}^{-1-} \mathrm{Bax}^{-/-} \mathrm{IL}-3-$ dependent cells were incubated with $\mathrm{Bax}$ and various $\mathrm{BH} 3$ peptides. ER membrane permeability assays were carried out (Supplementary Figure 4). Although some $\mathrm{BH} 3$ peptides (Bid, Bim, and Bmf) were able to function with Bax to release ER luminal proteins, others (Bnip3, Bik, Hrk, and Bad) failed to permeabilize the ER membrane in the presence of Bax (Table 1). The effects of
BH3 peptides on Bax-dependent ER membrane permeabilization are largely consistent with their activities in permeabilizing the MOM, ${ }^{29,30}$ suggesting that $\mathrm{BH} 3$ peptides derived from $\mathrm{BH} 3-$ only members function through a similar mechanism to activate Bax on the ER membrane and the MOM.

Next, we investigated whether antiapoptotic Bcl- $\mathrm{X}_{\mathrm{L}}$ was able to maintain ER membrane permeability in vitro under apoptotic conditions. ER membrane permeability assays were carried out using $\mathrm{ER} / \mathrm{microsomal}$ vesicles isolated from $\mathrm{Bak}^{-1-} \mathrm{Bax}^{-1-} \mathrm{IL}-3-d e p e n d e n t$ cells or $\mathrm{Bak}^{-1-} \mathrm{Bax}^{-1-} \mathrm{MEFs}$ (Figure 7). The addition of $\mathrm{Bcl}-\mathrm{X}_{\mathrm{L}}$ alone had a minimal effect on the release of PDI. In the presence of both Bax and tBid, $\mathrm{Bcl}-\mathrm{X}_{\mathrm{L}}$ was able to prevent $\mathrm{PDI}$ release, reminiscent of its ability to maintain MOM integrity under similar conditions. ${ }^{20,30}$ Our data suggest that $\mathrm{Bcl}-\mathrm{X}_{\mathrm{L}}$ maintains $\mathrm{ER}$ membrane permeability to ER luminal proteins in a manner similar to its activity on MOM permeability.

tBid induces Bax association with the ER membrane. As Bax translocation to the ER membrane correlated with increased ER membrane permeability in cells under ER stress (Figure 4), we examined whether it could be recapitulated in vitro. $\mathrm{ER} / \mathrm{micros}$ al vesicles isolated from IL-3-dependent $\mathrm{Bak}^{-1-} \mathrm{Bax}^{-1-}$ cells were first incubated with various combinations of $\mathrm{Bcl}-2$ proteins (Figure $8 \mathrm{a}-\mathrm{c}$ ). Then microsomal vesicles were treated with $100 \mathrm{mM} \mathrm{Na}_{2} \mathrm{CO}_{3}$ to remove proteins loosely attached to vesicles. The presence of Bax, PDI, GRP78/BiP, calnexin, and Tom20 was analyzed by western blotting. Tom20 was not detected in ER vesicle samples, indicating that ER vesicles had little mitochondria contamination. There was some Bax tightly attached to the 

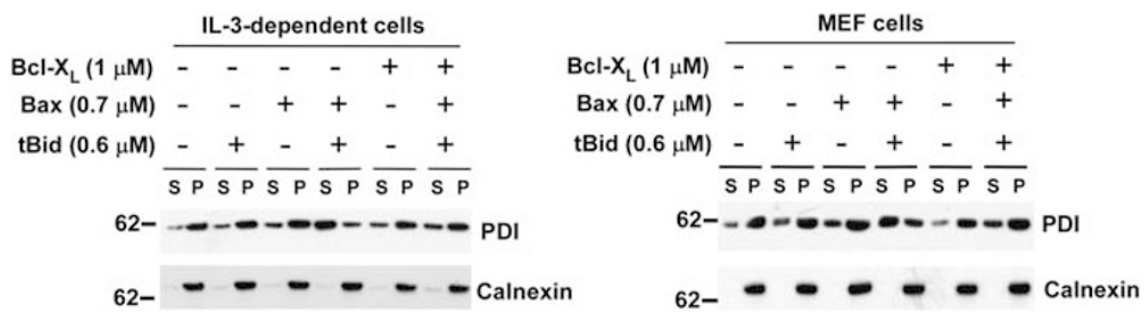

Figure $7 \mathrm{Bcl}-\mathrm{X}_{\mathrm{L}}$ antagonizes the effects of Bax and tBid on ER membrane permeability. $\mathrm{Bcl}-\mathrm{X}_{\mathrm{L}}$ inhibits the release of the ER luminal protein PDI in vitro. The indicated amounts of $\mathrm{Bcl}-2$ proteins were incubated with $\mathrm{ER} /$ microsomal vesicles isolated from IL-3-dependent $\mathrm{Bak}^{-1-} \mathrm{Bax}^{-1-} \mathrm{cells}$ or Bak ${ }^{-1-} \mathrm{Bax}^{-l-} \mathrm{MEF}$ cells, as described in Materials and Methods. The release of PDI from ER/microsomal vesicles was determined by western blotting. P, pellet (ER vesicle fraction); S, supernatant (released fraction)

a

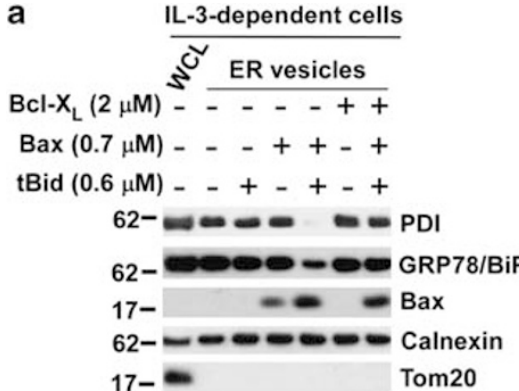

d

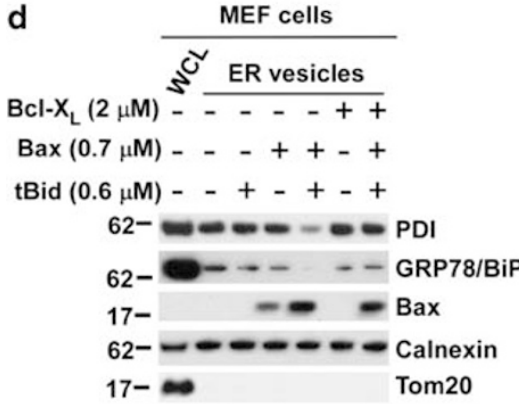

b
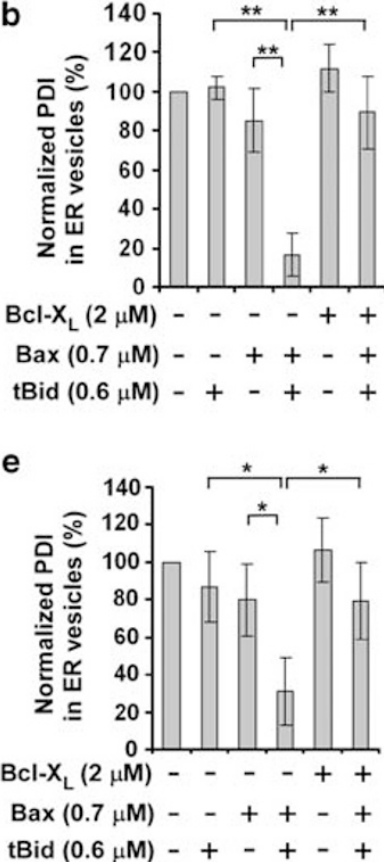

C

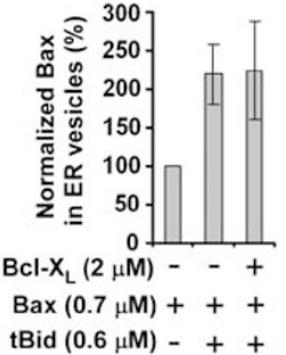

f

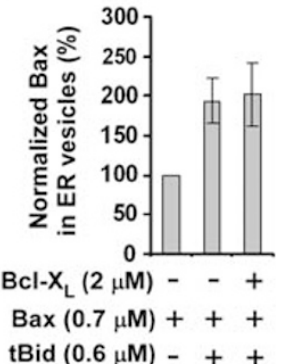

Figure 8 tBid promotes Bax association with the ER membrane. (a) ER vesicles isolated from IL-3-dependent Bak ${ }^{-1-}$ Bax $^{-1-}$ cells were incubated with the indicated amounts of $\mathrm{Bcl}-2$ proteins, followed by treatment with $100 \mathrm{mM} \mathrm{Na}_{2} \mathrm{CO}_{3}(\mathrm{pH}$ 11.3), as described in Materials and Methods. PDI and Bax in the ER vesicle fractions were determined by western blotting. (b) The summary of normalized PDI levels in the ER vesicles shown in a. As described in Materials and Methods, the normalized values of PDI levels were calculated as a percentage of relative PDI in the sample with buffer incubation only. Data represent the mean \pm S.D. of three independent experiments. (c) Normalized summary of Bax levels in the ER vesicles shown in a. As described in Materials and Methods, the normalized Bax levels were represented as a percentage of the relative Bax level in the sample incubated with Bax only. Data represent the mean \pm S.D. of three independent experiments. (d) ER/microsomal vesicles isolated from $\mathrm{Bak}^{-1-} \mathrm{Bax}^{-1-}$ MEFs were treated in the same manner as those from IL-3-dependent cells shown in a. PDI and Bax in the ER vesicles were detected by western blotting. $(\mathbf{e}, \mathbf{f})$ The levels of $\mathrm{PDI}$ and Bax shown in $\mathbf{d}$ were normalized as described in $\mathbf{b}$ and $\mathbf{c}$. Data represent the mean \pm S.D. of three independent experiments. Asterisks indicate ${ }^{\star} P<0.05$ or ${ }^{* *} P<0.01$, Student's unpaired $t$-test

ER membrane when ER vesicles were incubated with Bax alone, which could be caused by the precipitation of Bax protein after ultracentrifugation, as reported previously. ${ }^{30}$ Nevertheless, the basal amount of Bax on the ER membrane was not sufficient to mediate ER membrane permeabilization. The addition of tBid promoted the release of PDI and GRP78/BiP from vesicles and increased Bax association with the ER membrane, which is consistent with Bax translocation to the ER membrane in cells undergoing apoptosis (Figure 4). Although the addition of $\mathrm{Bcl}-\mathrm{X}_{\mathrm{L}}$ reversed $P D I$ and $G R P 78 / B i P$ release caused by Bax and tBid, it did not affect the amount of Bax in the ER membrane. One possible scenario is that $\mathrm{Bcl}-\mathrm{X}_{\mathrm{L}}$ interferes with a late step of ER membrane permeabilization, but not with the initial insertion of Bax into the ER membrane. Comparable results were also obtained using $\mathrm{ER} /$ microsomal vesicles isolated from $\mathrm{Bak}^{-1-} \mathrm{Bax}^{-1-}$ MEFs (Figure 8d, e and f), providing more evidence to the hypothesis that the activities of Bcl-2 proteins on the ER membrane are cell lineage-independent.

\section{Discussion}

ER stress-induced apoptosis is a well-described phenomenon, but the precise mechanisms through which ER stress is coupled with ultimate cell death are not well understood. In this study, we investigated the role of $\mathrm{Bcl}-2$ proteins in 
modulating ER membrane permeability to luminal proteins during apoptosis. To monitor the distribution of exogenously expressed YFP targeted to the ER lumen in asynchronized cell populations, we used a time-lapse confocal microscope approach. ER stress inducers, but not the genotoxic reagent actinomycin D, induced the release of ER-YFP in a Bak/Bax-dependent manner. Similarly, endogenous ER luminal proteins seemed to be released into the cytosol on ER stress treatment. Furthermore, the flux of ER luminal proteins likely occurred independently of MOM permeabilization. In vitro ER membrane permeability assays showed that proapoptotic $\mathrm{Bcl}-2$ proteins induced ER membrane permeabilization to luminal proteins, whereas antiapoptotic $\mathrm{Bcl}-\mathrm{X}_{\mathrm{L}}$ inhibited the release. The increased ER membrane permeability mediated by proapoptotic $\mathrm{Bcl}-2$ proteins seemed to be nonselective to luminal proteins, suggesting that $\mathrm{Bcl}-2$ proteins regulate $\mathrm{ER}$ membrane permeability in vitro in a manner similar to their activities on the MOM. Together, our studies provide molecular evidence that $\mathrm{Bcl}-2$ proteins regulate ER membrane permeability during ER stressinduced apoptosis.

Although MOM permeabilization has been well studied, little is known about the modulation of ER membrane permeability to luminal proteins during apoptosis. The redistribution of ER luminal proteins from the ER to the Golgi apparatus has been observed previously during ER stress induced by $\mathrm{Ca}^{2+}$ ionophore treatment. ${ }^{31}$ However, this process is likely to be different from $\mathrm{Bcl}-2$ protein-mediated $\mathrm{ER}$ luminal protein release described here. First, the changes in luminal protein distribution originally reported were associated with $\mathrm{ER} \mathrm{Ca}^{2+}$ store depletion, as tunicamycin failed to induce the translocation. In the present experiments, luminal protein release occurred independently of changes in ER $\mathrm{Ca}^{2+}$ concentration, as thapsigargin is known to be equally effective in depleting $\mathrm{ER} \mathrm{Ca}^{2+}$ store in both wild-type and $\mathrm{Bak}^{-1-} \mathrm{Bax}^{-1-}$ cells, ${ }^{21}$ but here, it only affected ER protein localization in wildtype cells (Figure 1). Second, ER-YFP proteins released from the ER lumen are evenly distributed in the cytosol and nuclei without obvious Golgi localization (Supplementary Movies 1 and 2). Finally, $\mathrm{Ca}^{2+}$ ionophore-induced $\mathrm{ER}$ luminal protein depletion was not detected in SV40-transformed fibroblasts, whereas ER luminal protein release mediated by proapoptotic $\mathrm{Bcl}-2$ proteins occurred in SV40-transformed MEFs. Thus, the luminal protein release described here is likely different from $\mathrm{Ca}^{2+}$ ionophore-induced luminal protein secretion reported previously.

Live cell imaging of cells undergoing apoptosis revealed that the kinetics of exogenously expressed ER-YFP release was almost identical in cells treated with two different ER stress inducers (Figure 1). As expected, the increase in ER membrane permeability to luminal proteins was dependent on Bak and Bax. The majority of ER-YFP release occurred within $40 \mathrm{~min}$ in MEF cells, suggesting that a secondary event, as proposed to be involved in the release of AIF from mitochondria, is not required. ${ }^{18}$ The rate of ER-YFP release was slower than the previously reported release of several apoptogenic proteins from mitochondria in HeLa cells undergoing apoptosis. ${ }^{17,18}$ It has been proposed that the speed of proapoptotic Bcl-2 protein-mediated formation of permeation channels on the MOM determines the release of mitochondrial protein. ${ }^{18}$ Because previous studies indicate that only about $10 \%$ of Bax and $15 \%$ of Bak are localized on the ER membrane, ${ }^{13,21}$ it is conceivable that the relatively slower release of ER luminal proteins could be attributed to lower concentrations of Bak or Bax proteins on the ER membrane. In addition, lipid components of intracellular organelle membrane could also influence the speed of permeation channel formation on the particular organelle membrane. ${ }^{25}$

MOM permeabilization has been proposed to be a committed no-return point for apoptosis. ${ }^{4}$ However, irreversible damage to the membrane of other intracellular organelles independently of MOM permeabilization could also represent a no-return point for cell death. One example is oxidative stress-induced lysosome rupture and subsequent release of lysosomal enzymes, which in turn directly impinge on mitochondria, resulting in cytochrome $c$ release. $^{32}$ Our data provide evidence that the initiation of increase in ER membrane permeability and mitochondrial membrane potential dissipation occurs concomitantly (Figure 2), implying that ER membrane permeability alterations could also serve as a committed no-return point for ER stress-induced apoptosis. Interestingly, the kinetics of ER-YFP redistribution and mitochondrial membrane potential dissipation in thapsigargin-treated MEFs was significantly different. Although the redistribution of most ER-YFP proteins occurred within $40 \mathrm{~min}$, it took more than $120 \mathrm{~min}$ for the complete dissipation of mitochondrial membrane potential, suggesting that mitochondria lose their function more slowly in thapsigargintreated MEF cells.

Currently, the exact role of ER stress-induced increase in ER membrane permeability to luminal proteins in apoptotic signaling remains unknown. Although unlikely, it is possible that ER stress renders the lipid environment of the ER membrane more susceptible to Bax insertion and/or Bak activation, resulting in ER membrane permeabilization irrelevant to apoptotic signaling. Many ER luminal proteins function as chaperones to facilitate appropriate protein folding and are generally considered to be prosurvival by assisting cells to adapt to unfolded protein response induced by ER stress. ${ }^{33}$ However, recent studies have shown that ER luminal chaperones localized outside the ER lumen exhibit unique proapoptotic activities in various apoptotic signaling pathways. For instance, the ER chaperone calreticulin expressed on the cell surface is a general recognition ligand to initiate clearance of dying cells through phagocytosis. ${ }^{34}$ Moreover, rapid translocation of calreticulin to the plasma membrane determines the cancer cell immunogenicity during apoptosis. ${ }^{35}$ Another ER luminal chaperone possessing proapoptotic activities is GRP78/BiP. In cells under ER stress induced by extracellular apoptotic stimuli, GRP78/BiP is translocated to the plasma membrane, where it serves as a cell surface receptor for the proapoptotic protein Par-4 to activate FADD/caspase8/ caspase 3 apoptotic signaling pathway. ${ }^{36}$ It is conceivable that certain luminal chaperones released from the ER lumen during ER stress could translocate to the cell surface and function in a variety of ways to facilitate apoptotic signaling cascade. Taken together, we suggest that the regulation of ER membrane permeability to luminal proteins by $\mathrm{Bcl}-2$ proteins may be involved in ER stress-induced apoptosis. 


\section{Materials and Methods}

Cell culture and reagents. Immortalized IL-3-dependent $\mathrm{Bak}^{-1-} \mathrm{Bax}^{-1-}$ hematopoietic cells were cultured as described previously. ${ }^{37}$ Wild-type murine Bak and Bax cDNAs were reexpressed in IL-3-dependent $\mathrm{Bak}^{-1-} \mathrm{Bax}^{-1-}$ cells by retroviral infection and stable clones expressing Bak and Bax were selected as described previously. ${ }^{37}$ Wild-type and $\mathrm{Bak}^{-1-} \mathrm{Bax}^{-1-} \mathrm{MEF}$ cells were cultured as described previously. ${ }^{13}$ Antibodies used were anti-actin mAb (Sigma, St. Louis, MO, USA), anti-Bax pAb (Santa Cruz, Santa Cruz, CA, USA), anti-Calnexin pAb (Assay Designs, Ann Arbor, MI, USA), anti-cytochrome $c$ mAb (Becton Dickinson, Franklin Lakes, NJ, USA), anti-ERp29 pAb (Affinity BioReagents, Rockford, IL, USA), antiGRP78/BiP mAb (Assay Designs), anti-PDI pAb (Becton Dickinson), anti-Tom20 pAb (western blotting; Santa Cruz), Alexafluor 488 Goat anti-mouse (Molecular Probes, Eugene, OR, USA), and Alexafluor 594 Goat anti-rabbit (Molecular Probes). Recombinant $\mathrm{Bcl}-2$ proteins ( $\mathrm{hBcl}-\mathrm{X}_{\mathrm{L}}, \mathrm{htBid}$, and $\mathrm{hBax}$ ) were acquired as described previously. ${ }^{38,39}$ All $\mathrm{BH} 3$ peptides were purchased from AnaSpec (San Jose, CA, USA) with over $95 \%$ purity and dissolved in solvents recommended by the manufacturer at the concentration of $5 \mathrm{mM}$.

Time-lapse confocal microscopy. Cells were transiently transfected with the plasmid pEYFP-ER (Clontech, Mountain View, CA, USA) using an Amaxa nucleofector device (Lonza, Allendale, NJ, USA) following the manufacturer's instructions and seeded into glass-coverslip-bottomed $35 \mathrm{~mm}$ dishes (WPI Inc, Sarasota, FL, USA). pEYFP-ER is constructed with a calreticulin ER-targeting sequence at its $\mathrm{N}$-terminus and the ER-retention sequence, KDEL, at its $\mathrm{C}$-terminus. After $24 \mathrm{~h}$ in culture, the dishes were placed into a miniature tissue culture incubator (DH-40i; Warner Instruments, Hamden, CT, USA) mounted onto an Olympus IX71 inverted microscope (Olympus, Center Valley, PA, USA). Individual cells were visualized with a $\times 60$ oil immersion objective and confocal images acquired using a VT-Infinity 3 scanning unit (VisiTech, Alexandria, VA, USA). A motorized stage enabled the capture of multiple image fields from the same dish. Cells were treated with apoptotic stimuli and confocal images acquired for each field at $10 \mathrm{~min}$ intervals for up to $12 \mathrm{~h}$. Images were analyzed using Simple PCl 6 (Hamamatsu, Billerica, MA, USA) and the time course of YFP release from the ER quantified by calculating the punctate/diffuse index, originally described by Douglas Green's group, and defined as the standard deviation (S.D.) of the mean pixel intensity of each cell. ${ }^{18,40}$ Briefly, when YFP fluorescence is highly localized within the ER compartment, cells have a punctate staining pattern, thus the S.D. of the average pixel intensity will be high. In contrast, when YFP is distributed throughout the cell, the S.D. will be low. Thus, a change in the S.D. (punctate/diffuse index) from high to low is an index of YFP redistribution from the ER to the cytoplasm. To simultaneously image ER and mitochondria, ER-YFP-transfected cells were loaded with the mitochondrial membrane potential indicator TMRE $(50 \mathrm{nM}$ for $20 \mathrm{~min}$ at $37^{\circ} \mathrm{C}$; Invitrogen, Carlsbad, CA, USA).

Electron microscopy. MEF cells were fixed with $3 \%$ glutaraldehyde in $0.1 \mathrm{M}$ sodium cacodylate at $4{ }^{\circ} \mathrm{C}$ overnight. Before embedding, cells were treated with $2 \%$ osmium tetroxide followed by an increasing gradient dehydration step using ethanol and propylene oxide. Cells were then embedded in LX-112 epoxy plastic (Ladd Research, Williston, VT, USA). Ultrathin sections of $80 \mathrm{~nm}$ were cut, placed on uncoated copper grids and stained with lead citrate and saturated aqueous uranyl acetate. Images were examined with a Philips $\mathrm{CM} 12$ transmission electron microscope at $80 \mathrm{kV}$ (Philips, Andover, MA, USA).

Gel filtration analysis for released ER luminal proteins. A FPLC Superose 6 10/30 gel filtration column (GE Healthcare) was equilibrated using the equilibrium buffer ( $20 \mathrm{mM}$ Tris- $\mathrm{HCl}(\mathrm{pH} 7.4)$ and $500 \mathrm{mM} \mathrm{KCl}$ ) on a Biologic DuoFlow chromatography system (Bio-Rad, Hercules, CA, USA). The Superose 6 column was calibrated using gel filtration standards (Bio-Rad). Cytosolic fractions of MEF cells treated with thapsigargin were dialyzed against the equilibrium buffer and very little protein precipitation was detected after the dialysis. Samples $(250 \mu \mathrm{l})$ were loaded onto the equilibrated Superose 6 column. Fractions were eluted at a rate of $0.4 \mathrm{ml} / \mathrm{min}$ in $1 \mathrm{ml}$ fractions and 23 fractions were collected. A volume of $10.5 \mu \mathrm{l}$ of each fraction was loaded on a 4-12\% NuPAGE gradient gel (Invitrogen). The amounts of ER luminal proteins were detected by western blotting.

Detection of ER luminal protein release. MEF cells were collected and washed with $1 \times$ PBS, and resuspended in MS buffer $(5 \mathrm{mM}$ Tris- $\mathrm{HCl}(\mathrm{pH} 7.5)$, $210 \mathrm{mM}$ mannitol, $70 \mathrm{mM}$ sucrose, and $1 \mathrm{mM}$ EDTA) supplemented with protease inhibitors (Complete, Roche Diagnostics, Indianapolis, IN, USA). The cells were broken open by passing them through a ball-bearing homogenizer. The whole cell lysate was centrifuged at $80 \times g$ using a Sorvall Legend RT centrifuge (Thermo Scientific) for $10 \mathrm{~min}$ at $4{ }^{\circ} \mathrm{C}$ to eliminate large cellular debris and nuclei. An aliquot of each supernatant was reserved as whole cell lysate. The remaining supernatants were centrifuged in a TLA 100.2 rotor using a TL-100 tabletop ultracentrifuge (Beckman, Fullerton, CA, USA) at $10000 \times g$ for 25 min at $4{ }^{\circ} \mathrm{C}$ and subsequently at $350000 \times \mathrm{g}$ for $20 \mathrm{~min}$ at $4{ }^{\circ} \mathrm{C}$ to obtain the cytosolic supernatant fractions. Equivalent total protein amounts of whole cell lysates and corresponding volume equivalents of cytosolic fractions were electrophoresed in a $4-12 \%$ NuPAGE gel (Invitrogen). The presence of ER proteins was detected by western blotting.

Detection of Bax in ER/microsomal vesicles. MEFs or IL3-dependent cells were collected and broken open as described in the 'Detection of ER luminal protein release' section. The whole cell lysate was centrifuged at $80 \times g$ for $10 \mathrm{~min}$ at $4{ }^{\circ} \mathrm{C}$ and the supernatants were centrifuged at $10000 \times \mathrm{g}$ for $20 \mathrm{~min}$ at $4{ }^{\circ} \mathrm{C}$. The supernatants were then centrifuged at $350000 \times \mathrm{g}$ for $20 \mathrm{~min}$ at $4^{\circ} \mathrm{C}$ and $\mathrm{ER} /$ microsomal vesicle pellets were resuspended in either MS buffer or $100 \mathrm{mM}$ $\mathrm{Na}_{2} \mathrm{CO}_{3}$ (pH 11.3). After incubation on ice for $30 \mathrm{~min}$, samples were centrifuged at $350000 \times \mathrm{g}$ for $20 \mathrm{~min}$ and resuspended in MS buffer. The protein concentrations of purified $\mathrm{ER} /$ microsomal vesicles were measured by Bradford assay (Bio-Rad). Equal amounts of ER vesicles $(10 \mu \mathrm{g})$ were loaded in a $4-12 \%$ NuPAGE gradient gel (Invitrogen) and Bax was detected by western blotting. For cross-linking experiments, $0.1 \mathrm{mM} \mathrm{BMH}$ was added to whole cell lysate and incubated at $25^{\circ} \mathrm{C}$ for $30 \mathrm{~min}$. Then, the ER fractions were obtained from the cell lysate as described earlier. A measure of $10 \mu \mathrm{g}$ of total protein was separated on a $4-12 \%$ gradient NuPAGE gel. A polyclonal anti-Bax antibody was used to detect Bax.

In vitro ER membrane permeability assay. Cells were collected and broken open as described in the 'Detection of ER luminal protein release' section, except that the supernatants were centrifuged twice at $900 \times g$ for $10 \mathrm{~min}$ at $4{ }^{\circ} \mathrm{C}$ after large cellular debris and nuclei were removed. The supernatants were again centrifuged at $350000 \times \mathrm{g}$ for $20 \mathrm{~min}$ at $4{ }^{\circ} \mathrm{C}$ and $\mathrm{ER} /$ microsomal vesicles were obtained by resuspending pellets in MS buffer. The protein concentrations of purified ER vesicles were measured by Bradford assay. Purified ER vesicles $(0.5 \mu \mathrm{g} / \mu \mathrm{l})$ were incubated with different combinations of recombinant $\mathrm{Bcl}-2$ proteins in buffer containing $12 \mathrm{mM}$ HEPES (pH 7.5), $1.7 \mathrm{mM}$ Tris- $\mathrm{HCl},(\mathrm{pH} 7.5), 100 \mathrm{mM}$ $\mathrm{KCl}, 140 \mathrm{mM}$ mannitol, $23 \mathrm{mM}$ sucrose, $2 \mathrm{mM} \mathrm{KH}_{2} \mathrm{PO}_{4}, 1 \mathrm{mM} \mathrm{MgCl} 2,0.67 \mathrm{mM}$ EGTA and $0.6 \mathrm{mM}$ EDTA. After $37^{\circ} \mathrm{C}$ incubation for $60 \mathrm{~min}$ (vesicles isolated from IL-3-dependent cells) or $30 \mathrm{~min}$ (vesicles isolated from MEFs), the samples were centrifuged at $350000 \times g$ for $20 \mathrm{~min}$. The supernatants (released fractions) and the pellets (ER/microsomal vesicle fractions) were separated and resuspended in equal volumes of $1 \times$ LDS sample buffer (Invitrogen). The presence of ER luminal proteins was detected by western blotting. For alkali treatment, after incubation with various $\mathrm{Bcl}-2$ proteins, $\mathrm{ER} /$ microsomal vesicles were resuspended in $100 \mu \mathrm{l}$ of $100 \mathrm{mM} \mathrm{Na} \mathrm{CO}_{3}(\mathrm{pH} \mathrm{11.3)}$ and put on ice for $30 \mathrm{~min}$. Treated ER/microsomal vesicles were centrifuged at $350000 \times g$ for $20 \mathrm{~min}$ and vesicles were dissolved in $1 \times$ LDS sample buffer (Invitrogen). Proteins in the vesicle and supernatant fractions were detected by western blotting. The protein intensity was determined using ImageJ software (NIH, Bethesda, MA, USA). To normalize sample-loading variation, the relative levels of $P D I$ were first calculated by dividing the $P D I$ value into the corresponding value for calnexin. The normalized values of PDI levels were then calculated as a percentage of relative PDI in the control sample (buffer incubation only). Similarly, the relative levels of Bax were first measured as described for PDI, and then normalized as a percentage of the relative Bax level in the sample incubated with Bax only.

\section{Conflict of interest}

The authors declare no conflict of interest.

Acknowledgements. We are grateful to Drs John Eaton and Brian Wattenberg for advice. We also thank the Calcium Imaging Research Support Laboratory, Department of Physiology \& Biophysics, Rosalind Franklin University. This work was supported by Schweppe Foundation and Rosalind Franklin University (CW) and NIH grants CA106599 and RR018733 and funding from JG Brown Cancer Center (CL). 
1. Cory S, Adams JM. The Bcl2 family: regulators of the cellular life-or-death switch. Nat Rev Cancer 2002; 2: 647-656.

2. Danial NN, Korsmeyer SJ. Cell death: critical control points. Cell 2004; 116: 205-219.

3. Youle RJ, Strasser A. The BCL-2 protein family: opposing activities that mediate cell death. Nat Rev Mol Cell Biol 2008; 9: 47-59.

4. Chipuk JE, Green DR. How do BCL-2 proteins induce mitochondrial outer membrane permeabilization? Trends Cell Biol 2008; 18: 157-164

5. Lindsten T, Ross AJ, King A, Zong WX, Rathmell JC, Shiels HA et al. The combined functions of proapoptotic Bcl-2 family members bak and bax are essential for normal development of multiple tissues. Mol Cell 2000; 6: 1389-1399.

6. Wei MC, Zong WX, Cheng EH, Lindsten T, Panoutsakopoulou V, Ross AJ et al. Proapoptotic BAX and BAK: a requisite gateway to mitochondrial dysfunction and death Science 2001; 292: 727-730.

7. Germain M, Shore GC. Cellular distribution of Bcl-2 family proteins. Sci STKE 2003 2003: e10.

8. Jiang X, Wang X. Cytochrome C-mediated apoptosis. Annu Rev Biochem 2004; 73 $87-106$.

9. Boyce M, Degterev A, Yuan J. Caspases: an ancient cellular sword of Damocles. Cell Death Differ 2004; 11: 29-37.

10. Oakes SA, Lin SS, Bassik MC. The control of endoplasmic reticulum-initiated apoptosis by the BCL-2 family of proteins. Curr Mol Med 2006; 6: 99-109.

11. Pinton P, Rizzuto R. Bcl-2 and $\mathrm{Ca} 2+$ homeostasis in the endoplasmic reticulum. Cell Death Differ 2006; 13: 1409-1418.

12. Nutt LK, Chandra J, Pataer A, Fang B, Roth JA, Swisher SG et al. Bax-mediated Ca2+ mobilization promotes cytochrome c release during apoptosis. J Biol Chem 2002; 277 20301-20308.

13. Zong WX, Li C, Hatzivassiliou G, Lindsten T, Yu QC, Yuan J et al. Bax and Bak can localize to the endoplasmic reticulum to initiate apoptosis. J Cell Biol 2003; 162: 59-69.

14. Mathai JP, Germain M, Shore GC. BH3-only BIK regulates BAX,BAK-dependent release of $\mathrm{Ca} 2+$ from endoplasmic reticulum stores and mitochondrial apoptosis during stress-induced cell death. J Biol Chem 2005; 280: 23829-23836.

15. Rong $\mathrm{Y}$, Distelhorst $\mathrm{CW}$. Bcl-2 protein family members: versatile regulators of calcium signaling in cell survival and apoptosis. Annu Rev Physiol 2008; 70: 73-91.

16. de Brito OM, Scorrano L. Mitofusin 2 tethers endoplasmic reticulum to mitochondria Nature 2008; 456: 605-610.

17. Goldstein JC, Munoz-Pinedo C, Ricci JE, Adams SR, Kelekar A, Schuler M et al. Cytochrome $\mathrm{C}$ is released in a single step during apoptosis. Cell Death Differ 2005; 12 : 453-462.

18. Munoz-Pinedo C, Guio-Carrion A, Goldstein JC, Fitzgerald P, Newmeyer DD, Green DR Different mitochondrial intermembrane space proteins are released during apoptosis in a manner that is coordinately initiated but can vary in duration. Proc Natl Acad Sci USA 2006 103: 11573-11578.

19. Galluzzi L, Zamzami N, de La Motte RT, Lemaire C, Brenner C, Kroemer G. Methods fo the assessment of mitochondrial membrane permeabilization in apoptosis. Apoptosis 2007; 12: 803-813.

20. Leber B, Lin J, Andrews DW. Embedded together: the life and death consequences of interaction of the Bcl-2 family with membranes. Apoptosis 2007; 12: 897-911.

21. Scorrano L, Oakes SA, Opferman JT, Cheng EH, Sorcinelli MD, Pozzan T et al. BAX and BAK regulation of endoplasmic reticulum $\mathrm{Ca2+:}$ a control point for apoptosis. Science 2003; 300: 135-139.
22. Fujiki $\mathrm{Y}$, Hubbard AL, Fowler S, Lazarow PB. Isolation of intracellular membranes by means of sodium carbonate treatment: application to endoplasmic reticulum 1. J Cell Biol 1982; 93: 97-102.

23. Gajkowska B, Wojewodzka U, Gajda J. Translocation of Bax and Bid to mitochondria, endoplasmic reticulum and nuclear envelope: possible control points in apoptosis 1. J Mol Histol 2004; 35: 11-19.

24. Upton JP, Austgen K, Nishino M, Coakley KM, Hagen A, Han D et al. Caspase-2 cleavage of $\mathrm{BID}$ is a critical apoptotic signal downstream of endoplasmic reticulum stress. Mol Cell Biol 2008; 28: 3943-3951.

25. Kuwana T, Mackey MR, Perkins G, Ellisman MH, Latterich M, Schneiter R et al. Bid, Bax, and lipids cooperate to form supramolecular openings in the outer mitochondrial membrane. Cell 2002; 111: 331-342.

26. Smith MI, Deshmukh M. Endoplasmic reticulum stress-induced apoptosis requires bax for commitment and Apaf-1 for execution in primary neurons. Cell Death Differ 2007; 14: $1011-1019$

27. Li J, Lee B, Lee AS. Endoplasmic reticulum stress-induced apoptosis: multiple pathways and activation of p53-up-regulated modulator of apoptosis (PUMA) and NOXA by p53. J Biol Chem 2006; 281: 7260-7270.

28. Puthalakath H, O'Reilly LA, Gunn P, Lee L, Kelly PN, Huntington ND et al. ER stress triggers apoptosis by activating BH3-only protein Bim. Cell 2007; 129: 1337-1349.

29. Chen L, Willis SN, Wei A, Smith BJ, Fletcher JI, Hinds MG et al. Differential targeting of prosurvival $\mathrm{Bcl}-2$ proteins by their $\mathrm{BH} 3-$ only ligands allows complementary apoptotic function. Mol Cell 2005; 17: 393-403.

30. Kuwana T, Bouchier-Hayes L, Chipuk JE, Bonzon C, Sullivan BA, Green DR et al. BH3 domains of BH3-only proteins differentially regulate Bax-mediated mitochondrial membrane permeabilization both directly and indirectly. Mol Cell 2005; 17: 525-535.

31. Booth $C$, Koch GL. Perturbation of cellular calcium induces secretion of luminal ER proteins. Cell 1989; 59: 729-737.

32. Yuan XM, Li W, Dalen H, Lotem J, Kama R, Sachs L et al. Lysosomal destabilization in p53-induced apoptosis. Proc Natl Acad Sci USA 2002; 99: 6286-6291.

33. Ron D, Walter P. Signal integration in the endoplasmic reticulum unfolded protein response. Nat Rev Mol Cell Biol 2007; 8: 519-529.

34. Gardai SJ, McPhillips KA, Frasch SC, Janssen WJ, Starefeldt A, Murphy-Ullrich JE et al. Cell-surface calreticulin initiates clearance of viable or apoptotic cells through transactivation of LRP on the phagocyte. Cell 2005; 123: 321-334.

35. Obeid M, Panaretakis T, Joza N, Tufi R, Tesniere A, van EP et al. Calreticulin exposure is required for the immunogenicity of gamma-irradiation and UVC light-induced apoptosis. Cell Death Differ 2007; 14: 1848-1850.

36. Burikhanov R, Zhao Y, Goswami A, Qiu S, Schwarze SR, Rangnekar VM. The tumor suppressor Par-4 activates an extrinsic pathway for apoptosis. Cell 2009; 138: 377-388.

37. Lum JJ, Bauer DE, Kong M, Harris MH, Li C, Lindsten T et al. Growth factor regulation of autophagy and cell survival in the absence of apoptosis. Cell 2005; 120: 237-248.

38. White C, Li C, Yang J, Petrenko NB, Madesh M, Thompson CB et al. The endoplasmic reticulum gateway to apoptosis by $\mathrm{Bcl}-\mathrm{X}(\mathrm{L})$ modulation of the InsP3R. Nat Cell Biol 2005; 7 : 1021-1028.

39. Li C, Wang X, Vais H, Thompson CB, Foskett JK, White C. Apoptosis regulation by Bcl-x(L) modulation of mammalian inositol 1,4,5-trisphosphate receptor channel isoform gating. Proc Natl Acad Sci USA 2007; 104: 12565-12570.

40. Bouchier-Hayes L, Munoz-Pinedo C, Connell S, Green DR. Measuring apoptosis at the single cell level. Methods 2008; 44: 222-228.

Supplementary Information accompanies the paper on Cell Death and Differentiation website (http://www.nature.com/cdd) 